\title{
Pengaruh Penambahan Ampas Kecap pada Jerami Fermentasi Terhadap Kualitas Fisik, pH dan Pertambahan Bobot Badan Sapi Brahman Cross (BX)
}

\section{The Influence of Dregs Soy Sauce Addition on Fermentated Straw Toward Physicall Quality, pH and Average Daily Gain (ADG) of Brahman Cross (BX)}

\author{
Finaya Eka Putri Suhudiyah ${ }^{1}$, Edy Susanto, S.Pt, M.P ${ }^{2}$, Drh. Muridi Qomaruddin, MM $^{3}$ \\ ${ }^{1}$ Mahasiswa Fakultas Peternakan \\ ${ }^{2}$ Dosen Pembimbing Utama \\ ${ }^{3}$ Dosen Pembimbing Pendamping \\ Program Studi Peternakan \\ Fakultas Peternakan, Universitas Islam Lamongan (UNISLA)
}

\begin{abstract}
RINGKASAN
Tujuan dari penelitian ini adalah untuk mengetahui pengaruh penambahan ampas kecap pada jerami fermentasi terhadap kualitas fisik, $\mathrm{pH}$ dan pertambahan bobot badan sapi Brahman Cross(BX). Materi yang digunakan dalam penelitian ini adalah 18 ekor sapi Brahman Cross (BX) dengan bobot awal 200-300 kg/ekor, jerami padi kering dan ampas kecap. Metode yang digunakan dalam penelitian ini adalah Rancangan Acak Lengkap yang terdiri dari 3 perlakuan dan 3 ulangan. Adapun 3 perlakuan tersebut terdiri dari jerami padi tanpa fermentasi, penambahan ampas kecap 5\% dan penambahan ampas kecap 10\%. Setiap ulangan di isi 2 ekor sapi. Variable yang diamati dalam penelitian ini adalah kualitas fisik, $\mathrm{pH}$ dan pertambahan bobot badan sapi Brahman Cross (BX). Data dianalisis dengan metode statistik Rancangan Acak Lengkap. Penimbangan bobot badan dilakukan setiap satu bulan sekali. Hasil penelitian menunjukkan bahwa penambahan ampas kecap pada jerami fermentasi tidak berpengaruh nyata $(\mathrm{P}>0,05)$ terhadap pertambahan bobot badan sapi Brahman Cross (BX). Akan tetapi pertambahan bobot badan sapi Brahman Cross yang mengkonsumsi pakan jerami fermentasi dengan ampas kecap lebih tinggi dibandingkan dengan control $\left(\mathrm{P}_{0}\right)$ dengan rata-rata peningkatan $0,25 \mathrm{~kg} / \mathrm{hari}$.

Kata Kunci : Ampas kecap, jerami fermentasi, kualitas fisik, pH , Pertambahan Bobot Badan, Sapi Brahman Cross (BX)
\end{abstract}

\begin{abstract}
The main purpose of this research is for knowing the influence of dregs soy sauce addition on fermentated straw toward physicall quality, $\mathrm{pH}$ and Average Daily Gain (ADG) of Brahman Cross (BX). The materials of this research was eighteen cattle of Brahman Cross $(B X)$ with initial weight 200 until $300 \mathrm{~kg} / \mathrm{tails}$, dried straw, and dreg of soy sauce. This research method is a completely randomized design consisting of 3 treatments, 3 replications. The treatments include of straw without fermentation, the addition of dregs soy sauce $5 \%$ and the addition of dregs soy sauce 10\%. Each of replications consist of two cows. The variable that be observed in this research is physicall quality, $\mathrm{pH}$ and Average Daily Gain (ADG) of Brahman Cross (BX). This result of research is analyzed with completely randomized design. Body weight's weighing is performed each month. This result of research shows that the addition of dregs soy sauce on fermentated straw doesn't give a real influence $(\mathrm{P}>0,05)$ toward the Average Daily Gain (ADG) of Brahman Cross (BX). But the Average Daily Gain (ADG) of Brahman Cross (BX) which eat the straw's fermentation with dregs soy sauce are higher than control $\left(\mathrm{P}_{0}\right)$ with an average increase of $0,25 \mathrm{~kg}$.

Keyword: Dregs soy sauce, fermentated straw, physicall quality, pH, Average Daily Gain (ADG), Brahman Cross $(\mathbf{B X})$

\section{PENDAHULUAN}

Indonesia sebagai negara tropis yang secara geografis memiliki dua musim yaitu musim penghujan dan musim kemarau serta

secara langsung dapat mempengaruhi potensi ketersediaan hijauan pakan. Kondisi daerah tropis yang kurang menguntungkan merupakan faktor lingkungan yang berpengaruh terhadap
\end{abstract}


perkembangan ternak pada status fisiologis yang berbeda-beda. Kondisi badan ternak merupakan cerminan kondisi ternak terhadap kemampuan biologis termasuk aktivitas produksi dan dapat tampak dengan perubahan laju pertumbuhan berupa tampilan bobot badan. Laju pertumbuhan merupakan salah satu performans yang digunakan sebagai petunjuk keberhasilan pemeliharaan sapi potong ( Wijono dkk, 2006 ) dalam Ramadhanty (2014).

Semakin hari kebutuhan daging sapi semakin meningkat. Tentunya ternak sapi yang awalnya dari gembalaan dengan pakan terbatas, kini semakin dikembangkan apalagi ketersediaan lahan penggembalaan semakin terbatas. Kondisi ini menambah keingian manusia untuk membuka usaha peternakan sapi secara intensif dan professional ( Yulianto dan Saparinto, 2010 ).

Populasi sapi potong di Indonesia khusunya di Jawa Timur tahun 2015 mencapai 4.326.261 ekor (Direktorat Jenderal Peternakan dan Kesehatan Hewan, 2015). Sementara produksi daging hanya 90.163 ton. Kondisi demikian sudah tentu tidak dapat dipertahankan sehingga perlu lebih memberikan kesempatan bagi para pelaku usaha penggemukan sapi potong untuk mengembangkan usahanya. Seperti usaha penggemukan sapi potong kelompok ternak "Sumber Jaya" yang terletak di dusun Pilanggot, desa Wonokromo, kecamatan Tikung. Kelompok ternak "Sumber Jaya" mulai berdiri pada 13 Maret 2006 dengan populasi 22 ekor dan sekarang mencapai 155 ekor. Dengan jumlah pejantan 150 ekor dan jumlah betina 5 ekor. Usaha tersebut memiliki peran dalam rangka mendukung peningkatan prduksi daging sapi potong.

Pertumbuhan ternak tergantung dari pakan, genetis, dan perawatan. Namun, pemenuhan pakan merupakan faktor dominan dibandingkan faktor genetis dan perawatan. Dengan demikian, kebutuhan pakan ternak harus dipenuhi dengan baik. Pakan yang diberikan pada ternak dengan komposisi sederhana, tetapi tidak mengurangi kandungan gizinya dapat menekan biaya produksi selama pemeliharaan. Sebab, bahan baku tersebut bisa diperoleh dari limbah, sisa produksi, tidak membutuhkan proses industrialisasi, dan dapat menghemat overhead cost ( Yulianto dan Saparinto, 2010 ) .
Persediaan rumput yang merupakan sumber pakan hijauan di Indonesia sangat dipengaruhi oleh musim. Saat musim hujan, tanaman pakan ternak dapat tumbuh baik, sehingga kebutuhan pakan hijauan dapat tercukupi. Sebaliknya pada musim kemarau, tanaman hijauan yang dihasilkan akan sangat berkurang dalam jumlah dan kualitasnya. Untuk mengatasi hal ini umumnya peternak menggunakan limbah pertanian yang tersedia di sekitarnya untuk pakan ternaknya (Astuti dan Sukarni, 2004).

Limbah pertanian adalah sisa tanaman pertanian pasca panen setelah diambil hasil utamanya. Limbah pertanian ini merupakan bahan lignoselulosa yang banyak dihasilkan tapi belum digunakan secara efisien. Salah satu jenis limbah pertanian yang potensial sebagai pakan ternak adalah jerami padi (Astuti dan Sukarni, 2004).

Agar jerami padi dapat digunakan sebagai pakan ternak perlu ditingkatkan kualitasnya sehingga dapat memperbaiki nilai nutrisi dan kecernaan. Untuk itu perlu dilakukan suatu teknologi untuk peningkatan kualitas jerami padi sebagai pakan ternak. Teknologi yang diperlukan haruslah mudah dan praktis serta ekonomis.Untuk meningkatkan kualitas jerami sebagai pakan ternak maka perlu dilakukan pengolahan jerami. Macam-macam pengolahan jerami untuk meningkatkan kualitasnya dengan antara lain adalah cara fermentasi.

Karakteristik jerami padi adalah lignin dan silika yang tinggi, maka prinsip pengolahan adalah untuk memecah ikatan lignin dan silika menjadi ikatan yang sederhana sehingga mudah dicerna. Menurut Imam (2011) dalam Masnun (2014) amoniasi dan fermentasi jerami padi merupakan suatu metode pengolahan jerami yang dapat memecah ikatan selulosa, hemiselulosa dan lignin sehingga jerami lebih mudah dicerna.

Ampas kecap yang merupakan limbah padat dari industri kecap , dihasilkan sebesar $59,70 \%$ dari total bahan baku kedelai yang digunakan (Sofyan dkk, 2000). Banyak produsen ampas kecap yang mengaku kesulitan dalam menangani limbah padat kecap ini , bahkan seringkali ampas kecap ini langsung 
dibuang ke TPA / Tempat Pembuangan Akhir ( Nugroho dkk, 1998 ).

Sehingga perlu dilakukan penelitian tentang Pengaruh Penambahan Ampas Kecap Pada Jerami Terhadap Kualitas Fisik, PH dan Pertambahan Bobot Badan Sapi Brahman Cross $(B X)$ di Kelompok Ternak Sumber Jaya Dusun Pilanggot Desa Wonokromo Kecamatan Tikung Kabupaten Lamongan.

\section{MATERI DAN METODE}

Penelitian ini menggunakan metode percobaan eksperimen. Teknik pengumpulan data pengamatan yang digunakan dalam penelitian ini adala sebagai berikut :

- Metode Wawancara Langsung

- Metode Observasi

- Metode Kuisioner

\section{RANCANGAN PERCOBAAN}

Penelitian ini dilakukan dengan menggunakan Rancangan Acak Lengkap (RAL). Terdiri dari 3 perlakuan dan setiap perlakuan diulang sebanyak 3 kali. Setiap perlakuan dan ulangan menggunakan 2 ekor sapi potong jenis Brahman Cross $(B X)$. Metode yang digunakan dalam penelitian ini adalah eksperimen. Perlakuan yang diterapkan adalah :

(P0): Jerami padi tanpa perlakuan

(P1): Jerami padi 95\% + Ampas kecap 5\%

(P2): Jerami padi 90\% + Ampas kecap 10\%

\section{VARIABEL PENGAMATAN}

1. Variabel bebas dalam penelitian ini adalah penambahan ampas kecap

2. Variabel terikat:

- Variabel utama : Pertambahan Bobot Badan

- Variabel pendukung : Kualitas fisik pakan yang meliputi warna, tekstur, bau dan $\mathrm{pH}$ jerami fermentasi.

\section{ANALISIS DATA}

Penelitian ini dilakukan selama dua bulan, tiga minggu untuk proses fermentasi . proses fermentasi jerami padi dilakukan dengan metode HARYANTO (2003). Rancangan percobaan yang digunakan adalah Rancangan Acak Lengkap ( Raupong dan Anisa, 2011 ).
Data yang diperoleh dianalisa menggunakan ANOVA. Rumus matematikanya sebagai berikut :

$$
\begin{aligned}
& \quad Y i j k=\mu+\sigma_{i}+\varepsilon_{i j k} \\
& \mathrm{i}=1,2, \ldots \ldots, \mathrm{t} \\
& \mathrm{j}=1,2, \ldots \ldots ., \mathrm{r} \\
& \text { Dimana: }
\end{aligned}
$$

$\mathrm{y}_{\mathrm{ij}}=$ Pengamatan pada perlakuan ke- $i$ dan ulangan ke- $j$

$\mu \quad=$ Rataan umum

$\sigma_{\mathrm{i}} \quad=$ Pengaruh perlakuan ke- $i$

$\varepsilon_{\mathrm{ij}}=$ Error (pengaruh acak) pada perlakuan ke- $i$ dan ulangan ke-j

Pertambahan bobot badan $(\mathrm{kg})$ diukur menggunakan rumus menurut Cole (1966) :

Dimana :

$$
P P B H=\frac{w 2-w 1}{t 2-t 1}
$$

$\mathrm{t}_{1}=$ waktu awal pengamatan (hari)

$\mathrm{t}_{2}=$ waktu akhir pengamatan (hari)

$\mathrm{w}_{1}=$ bobot badan awal $(\mathrm{kg})$

$\mathrm{w}_{2}=$ bobot badan akhir $(\mathrm{kg})$

\section{UJI pH}

\section{HASIL DAN PEMBAHASAN}

Berdasarkan hasil pengamatan yang telah dilakukan terhadap nilai $\mathrm{pH}$ penambahan ampas kecap pada jerami padi dapat dilihat pada Tabel 4.4 .

Tabel 4.4 Hasil Pengamatan Nilai pH Pakan Fermentasi

\begin{tabular}{|l|c|}
\hline Sample Perlakuan & Nilai $\mathrm{pH}$ \\
\hline $\mathrm{P}_{\mathrm{o}}$ ( Jerami padi tanpa perlakuan ) & 7,21 \\
\hline $\mathrm{P}_{1}$ (Jerami padi 95\% + Ampas kecap 5\%) & 5,21 \\
\hline $\mathrm{P}_{2}$ (Jerami padi 90\% + Ampas kecap 10\%) & 5,05 \\
\hline
\end{tabular}

Sumber : Data diolah primer (2016)

Berdasarkan data diatas, nilai $\mathrm{pH}$ jerami antara $\mathrm{P}_{0}$ ( Jerami padi tanpa perlakuan ) dengan $\mathrm{P}_{1}$ ( Jerami padi $95 \%$ + ampas kecap 5\% ) dengan $\mathrm{P}_{2}$ ( Jerami padi $90 \%+$ ampas kecap $10 \%$ ) tidak berbeda terlalu jauh. Dapat dilihat pada Tabel bahwa perlakuan $\mathrm{P}_{0}$ memiliki nilai $\mathrm{pH}$ yang tinggi yaitu 7,21 sedangkan $\mathrm{P}_{1}$ dan $\mathrm{P}_{2}$ memiliki nilai $\mathrm{pH}$ yang relatif lebih rendah. Perlakuan tanpa penambahan Ampas Kecap relatif lebih tinggi nilai pHnya dibandingkan pada perlakuan $\mathrm{P}_{1}$ dan $\mathrm{P}_{2}$. Meskipun tidak berbeda terlalu jauh antar perlakuan, terdapat kecenderungan penurunan nilai $\mathrm{pH}$ pada ransum 
yang ditambahkan Ampas Kecap. Ampas kecap memiliki kandungan protein yang cukup tinggi yaitu 10.32\% (Nugroho, 1998). Sedangkan yang bisa menurunkan $\mathrm{pH}$ adalah karbohidrat yang tinggi. Hal ini sejalan dengan pendapat Perry dkk, (2003) dalam Jasin (2014) bahwa penambahan bahan kaya akan karbohidrat dapat mempercepat penurunan $\mathrm{pH}$ silase karena karbohidrat merupakan energi bagi bakteri pemberntuk asam laktat.

Dari hasil penelitian, didapatkan $\mathrm{pH}$ dengan nilai 5,05. Hal ini sesuai dengan penelitian yang dilakukan oleh Asngad (2005) yaitu $\mathrm{pH}$ fermentasi yang baik berkisar antara 46. Menurut Hidayat (2000) bahwa tingkat keasaman sangat berpengaruh dalam perkembangan bakteri.

\section{UJI ORGANOLEPTIK}

Berdasarkan hasil pengamatan yang telah dilakukan, berikut adalah data yang diperoleh dari hasil uji organoleptik pakan yang kemudian diolah sebagaimana dalam Tabel 4.6.

Tabel 4.6 Rata-Rata Hasil Uji

Organoleptik

\begin{tabular}{|l|c|c|c|}
\hline \multirow{2}{*}{ Parameter } & \multicolumn{3}{|c|}{ Perlakuan } \\
\cline { 2 - 4 } & $\mathrm{P}_{0}$ & $\mathrm{P}_{1}$ & $\mathrm{P}_{2}$ \\
\hline Bau & 1 & 2 & 2 \\
\hline Warna & 2 & 1 & 3 \\
\hline Tekstur & 1 & 2 & 2 \\
\hline \multicolumn{4}{|c|}{ * *Indikator : } \\
*Warna:1=Hitam \\
2=Agak asam \\
2=Agak lapuk \\
3=Asam \\
3s=Serat lapuk
\end{tabular}

Berdasarkan Tabel diatas terdapat kecenderungan perbedaan tiap perlakuan. Pada perlakauan $\mathrm{P}_{0}$ ( Jerami padi tanpa fermentasi ) memiliki karakteristik bau tidak asam, berwarna agak cokelat dan bertekstur tidak lapuk. Pada perlakuan $\mathrm{P}_{1}$ ( Jerami Padi + Ampas Kecap 5\%) memiliki karakteristik bau agak asam, berwarna hitam dan bertekstur agak lapuk. Pada perlakuan $\mathrm{P}_{2}$ ( Jerami Padi + Ampas Kecap 10\% ) memiliki karakteristik bau agak asam, berwarna cokelat dan bertekstur agak lapuk. Pada perlakuan $\mathrm{P}_{1}$ jerami fermentasi berwarna hitam, hal ini disebabkan teknis pembuatan pakan fermentasi kurang cermat sehingga menyebabkan kelambaban udara menjadi tinggi.

Berdasarkan hasil pengamatan uji organoleptik diatas, dapat disimpulkan bahwa kualitas pakan fermentasi pada perlakuan kedua $\left(\mathrm{P}_{2}\right)$ dikategorikan baik yaitu teksturnya agak lapuk,berwarna cokelat dan baunya agak asam. Menurut Siregar (1996) dalam Prabowo, dkk (2013) secara umum silase yang baik mempunyai ciri-ciri, yaitu rasa dan bau asam, tetapi segar dan enak, tekstur masih jelas, seperti alaminya. Berdasarkan Siregar (1996) dalam Prabowo, dkk (2013) dapat disimpulkan bahwa bau, warna dan tekstur pakan fermentasi sudah sesuai walaupun baunya masih agak asam. Hal ini disebabkan karena kontrol fermentasi yang tidak sama antar perlakuan seperti kelembaban udara, penutup pakan, dan kadar air yang ditambahkan pada saat proses fermentasi.

3. Pengaruh Perlakuan Terhadap Pertambahan Bobot Badan Sapi Brahman Cross (BX)

Data pertambahan bobot badan sapi penelitian dan hasil analisis statistiknya dapat dilihat pada Tabel 4.7 berikut ini.

Tabel 4.7 Data Pertambahan Bobot Badan Sapi Brahman Cross (BX) (kg/ekor/hari)

\begin{tabular}{|c|c|c|c|c|c|}
\hline \multirow{2}{*}{ Perlaku } & \multicolumn{3}{|c|}{ Ulangan } & \multirow{2}{*}{ Total } & \multirow{2}{*}{ Rataan } \\
\cline { 2 - 5 } an & 1 & 2 & 3 & & \\
\hline $\mathrm{P}_{0}$ & 0,55 & 0,57 & 0,57 & 1,69 & 0,56 \\
\hline $\mathrm{P}_{1}$ & 0,64 & 0,41 & 0,51 & 1,56 & 0,52 \\
\hline $\mathrm{P}_{2}$ & 0,75 & 0,66 & 1,03 & 2,44 & 0,81 \\
\hline Total & 1,94 & 1,64 & 2,11 & 5,69 & 0,63 \\
\hline
\end{tabular}

Sumber : Data diolah primer (2016)

Berdasarkan data pada Tabel diatas menunjukkan bahwa perbedaan pertambahan bobot badan sapi $(\mathrm{P}>0,05)$ tidak berbeda nyata . Pada sapi yang diberi pakan $\mathrm{P}_{0}$ (Jerami Padi) bobot badan sapi Brahman Cross meningkat sebanyak 0,56kg, pada $\mathrm{P}_{1}$ (Jerami Padi 95\% + Ampas Kecap 5\%) bobot badan sapi Brahman Cross meningkat sebanyak $0,52 \mathrm{~kg}$ dan $\mathrm{P}_{2}$ (Jerami Padi 90\% + Ampas Kecap 10\%) bobot badan sapi Brahman Cross meningkat sebanyak 0,81kg. Menurut Rahmat dan Harianto (2012) dalam Arifbowo (2007) ampas kecap dapat diberikan langsung sebagai pakan ternak sampai 
jumlah 20\% dari ransum. Sedangkan pada perlakuan diatas penambahan ampas kecap sebanyak 5\% dan 10\% dari total ransum.

Ditambahkan Zahra (1996) dalam Nanda (2011) tingkat konsumsi ransum erat hubungannya dengan pertumbuhan, semakin banyak ransum yang dikonsumsi semakin tinggi pertambahan bobot badan yang dihasilkan. Pertambahan bobot badan yang tidak stabil antar tiap perlakuan dikarenakan tingkat konsumsi sapi pada tiap perlakuan berbeda. Pada perlakuan $\mathrm{P}_{1}$ tingkat konsumsi pakan cenderung menurunHasil analisis statistik menunjukkan bahwa pertambahan bobot badan sapi yang diberi ransum $\mathrm{P}_{0}$ ( Jerami Padi ) $\mathrm{P}_{1}$ ( Ampas Kecap 5\%), $\mathrm{P}_{2}$ (Ampas Kecap 10\%) yaitu ratarata $0,63 \mathrm{~kg} / \mathrm{ekor} / \mathrm{hari}$. Menurut Yulianto dan Saparinto, (2010) dengan pemeliharaan yang intensif, pertambahan berat badan sapi Brahman dewasa dapat mencapai $0,83-1,5 \mathrm{~kg} / \mathrm{hari}$ dengan presentase karkas 48,6-54,2\%.

Berdasarkan hal diatas, disimpulkan bahwa hasil penelitian ini belum mencapai pertambahan bobot badan standart. Sejalan dengan pendapat Sarwono dan Arianto (2007) dalam Nanda (2011) menyatakan bahwa kemampuan sapi mengkonsumsi ransum sangat terbatas. Keterbatasan itu dipengaruhi oleh faktor ternak, keadaan pakan, dan faktor luar, seperti suhu dan kelembaban udara. Diperkuat kembali oleh Yulianto dan Saparinto (2010) bahwa pakan silase sebaiknya diberikan $25-30 \%$ dari total kebutuhan.

1. Kesimpulan

Berdasarkan hasil penelitian yang telah dilakukan, dapat ditarik sebuah kesimpulan bahwa penambahan ampas kecap pada jerami fermentasi tidak memberikan pengaruh nyata $(\mathrm{P}>0,05)$ terhadap pertambahan bobot badan sapi Brahman Cross (BX). Akan tetapi pertambahan bobot badan sapi yang megkonsumsi jerami fermentasi dengan ampas kecap cenderung lebih tinggih dibandingkan kontrol $\left(\mathrm{P}_{0}\right)$ dengan rata-rata peningkatan sebesar $0,25 \mathrm{~kg} /$ hari.

\section{Saran}

Saran yang dapat diberikan dalam penggunaan ampas kecap pada jerami fermentasi untuk pertambahan bobot badan sapi adalah :
1. Sebaiknya ampas kecap diberikan lebih dari $10 \%$ untuk mendapatkan peningkatan bobot badan lebih dari $0.82 \mathrm{~kg}$, namun perlu dihitung efisiensi biaya ransumnya.

2. Sebaiknya dalam proses pembuatan pakan fermentasi lebih memperhatikan kelambaban pakan, penutup pakan fementasi, suhu serta kadar air yang ditambahkan pada proses fermentasi

\section{DAFTAR PUSTAKA}

Abdullah, Ahmad Sayid. 2015. Pengaruh Penambahan Ampas Tahu Dalam Penggunaan Konsentrat Dan Hijauan Terhadap Jumlah Konsumsi, PBB, Dan FCR Kelinci Lokal Jantan. Fakultas Peternakan. Universitas Islam Lamongan. Lamongan.

Aisyah, G. 1979. Faktor Anti Tripik Kedelai. Desertasi. Institut Pertanian Bogor. Indonesia.

Ahmad M, Nashir, 2008. Pembuatan Jerami Fermentasi. Lembar informasi pertanian (Liptan) IP2TP Mataram No. 01/Liptan/2000.Instalasi Penelitian dan Pengkajian teknologi Pertanian. Mataram.

Arifbowo, Nindya Agung. 2007. Pengaruh Suplementasi Ampas Tahu, Ampas Tempe dan Ampas Kecap Terhadap Kecernaan Bahan Kering Dan Bahan Organik Pada domba Lokal Jantan. Fakultas Pertanian. Universitas Sebelas Maret. SurakartaBlakely, J. dan Bade, D. H., 1992. Ilmu Peternakan IV. Yogyakarta: Gadjah Mada University Press

Astuti P, Sukarni S. 2004. Kinerja Domba Lokal yang Mendapatkan Limbah Padat (Blotong ) Industri Pabrik Gula. Karanganyar: APEKA.

Hardjosubroto, Wartono dan Jovita Maria Astuti. 1993. Buku Pintar Peternakan. PT Gramedia Widiasarana Indonesia. Jakarta.

Haryanto,B., Supriyati, A. Thalib dan S.N. Jarmani. 2005. Peningkatan Nilai Hayati Jerami Padi Melalui Bio-Proses Fermentative Dan Penambahan Zinc Organik. Pros. Seminar Nasional 
Teknologi Peternakan dan Veteriner. Bogor, 12-13 September 2005. Puslitbang Peternakan. Bogor. 473-478.

Herdoni, 2011. Pengolahan Limbah Pertanian Untuk Pakan Ternak.

Hidayat A. 2002. Keamanan Pangan. Bogor : Balai Penelitian Bioteknologi Tanaman Pangan

Jasin, Ismail. 2014. Pengaruh Penambahan Molases dan Isolat Bakteri Asam Laktat dari Cairan Rumen Sapi PO Terhadap Kualitas Silase Rumput Gajah (Pennisetum Purpureum). Fakultas Peternakan. Universitas Darul Ulum Islamic Centre. SUDIRMAN GUPPI. Unggaran.

Masnun. 2014. Teknologi Jerami Fermentasi Sebagai Pakan Ternak.

Nanda, Diana Delfia. 2011. Konsumsi Ransum Dan Pertambahan Bobot Badan Sapi Bali Yang Diberi Silase Daun Pelepah Kelapa Sawit Sebagai Subtitusi Rumput Gajah. Fakultas Pertanian Dan Peternakan. Universitas Islam Negeri Sultan Syarif Kasim Riau . Pekanbaru.

Nugroho, A., Setiatin, E., Tabrani, T., \& Surahmanto, H. 1998. Evaluasi Limbah Padat Kecap sebagai Pakan Ruminansia Berdasarkan Uji Degradasi Serat Terlarut dalam Asam. Pusat Penelitian Pengembangan Teknologi. Lembaga penelitian. Universitas Diponegoro. Semarang, hlm 1.

Prabowo, Agung., Susanti ,AE., Karman ,J. 2013. Pengaruh Penambahan Bakteri Asam Laktat Terhadap pH dan Penampilan Fisik Silase Jerami Kacang Tanah. Balai Pengkajian Tenologi Pertanian (BPTP). Sumatera Selatan

Ramadhanty, Dhian. 2014. Pertambahan Bobot Badan Sapi Brahman Cross (BX) Fase Starter Yang Dipelihara Secara Intensif di PT. BULI (Berdikari United Livestock) Kabupaten Sidenreng Rappang Pada Musim Yang Berbeda. Universitas Hasanuddin. Makassar

Raupong dan Anisa. 2011. Bahan Ajar Mata Kuliah Perancangan Percobaan. Makassar.
Santosa, Undang. 2002. Mengelola Peternakan Sapi Secara Profesional. Penebar Swadaya. Jakarta.

Sarwono, B dan H.B. Arianto. 2003. Penggemukan Sapi Potong Secara Cepat. Penebar Swadaya, Jakarta.

Sofyan, LA., Aboenawan, L., Laconi, E.B., Djamil, A. Ramli, N., Ridla, M., \& Lubis, A.D. 2000. Diktat Pengetahuan Bahan Makanan Ternak. Laboratorium Ilmu dan Teknologi Pakan, Fakultas Peternakan, IPB, Bogor.

Sudarmadji. S. 1984. Analisa Bahan Makanan dan Pertanian. Yogyakarta : Liberty.

Sulardjo. 1999. Usaha Meningkatkan Nilai Nutrisi Jerami Padi, SainTeks. Vol VII. NO. 3 : Universitas Semarang.

Suryaningrum, Lusi Herawati \& Azwar, Zafril Imran. 2011. Potensi Ampas Kecap Sebagai Alternatif Subtitusi Bungkil Kedelai Dalam Pakan Ikan. Balai Riset Perikanan Budidaya Air Tawar. Bogor

Sutrisno, Imam. 1985. Upaya Pemenuhan Kebutuhan Ternak Ruminansia. Fakultas Peternakan. UNDIP.

Yulianto, Purnawan dan Cahyo Saparinto. 2010. Pembesaran Sapi Potong secara Intensif. Penebar Swadaya. Jakarta.

Yunilas. 2009. Bioteknologi Jerami Padi Melalui Fermentasi Sebagai Bahan Pakan Ternak Ruminansia. Departemen Peternakan Fakultas Peternakan Universitas Sumatera Utara. Medan. 